\title{
11-ALLYLCYTISINE AND OTHER MINOR ALKALOIDS FROM UNRIPE SOPHORA SECUNDIFLORA FRUITS
}

\author{
W. J. KelleR* and M. HATFiELD ${ }^{\dagger}$ \\ *School of Pharmacy, Northeast Louisiana University, Monroe, LA 71209, U.S.A. \\ †College of Pharmacy, University of Michigan, Ann Arbor, MI 48109, U.S.A.
}

(Received 6 March 1979)

\begin{abstract}
Key Word Index-Sophora secundiflora; Leguminosae; quinolizidine alkaloids; 11 -allylcytisine; $\beta$-isosparteine; lupanine; rhombifoline.
\end{abstract}

\section{INTRODUCTION}

Sophora secundiflora (Ort.) Lag. ex DC. (Leguminosae) is a shrub native to the drier areas of the southwestern portions of the United States. The mature seeds from this plant are referred to as mescal beans, red beans and big drunk beans, and have been cited in the ethnobotanical literature [1-3] as being hallucinogenic because of their past use in certain native American ceremonies. A recent lay publication [4] has indicated that the mature seeds are part of the modern drug scene. These reports stimulated extensive investigations $[5,6]$ of the mature seed material resulting in the isolation of 6 known quinolizidine alkaloids (anagyrine, cytisine, $\Delta^{5}$-dehydrolupanine, epi-lupinine, $N$-methylcytisine, and sparteine). The present report describes the isolation and structure elucidation of a new alkaloid, 11-allylcytisine 1, from the green, unripe fruits of $S$. secundiflora. Rhombifoline, lupanine and $\beta$-isosparteine were also identified as being minor components in this material.<smiles>C=CCC1CCn2c(cccc2=O)C1</smiles>

\section{RESULTS AND DISCUSSION}

PLC of an extract from unripe $S$. secundiflora fruits on Si gel with $\mathrm{CHCl}_{3}-\mathrm{MeOH}-18 \mathrm{M} \mathrm{NH} \mathrm{NH}_{4} \mathrm{OH}$ (100:10:1) gave 3 bands of interest. One band was chromatographically homogeneous and proved to be identical (TLC, GLC, NMR, MS) with rhombifoline. Another band was a binary mixture consisting of sparteine and a trace of $\beta$-isosparteine (TLC, GLC, MS). The third band consisted of $N$-methylcytisine, previously undetected lupanine (TLC, GLC, MS), and the new alkaloid 11allylcytisine 1. PLC of this ternary mixture on Si gel with cyclohexane- $\mathrm{CHCl}_{3}-\mathrm{MeOH}-$ diethylamine $\quad(10: 1: 1: 1)$ was used to isolate 1 in pure form.

Spectral evidence suggested the structure of the new base as being an allyl derivative of cytisine. The IR spectrum revealed absorption bands at 2700-2800 (transquinolizidine), $1645\left(\alpha\right.$-pyridone $\mathrm{C}=0$ ) and $914 \mathrm{~cm}^{-1}$ $\left(-\mathrm{CH}=\mathrm{CH}_{2}\right)$. The ${ }^{1} \mathrm{H}$ NMR spectrum $(100 \mathrm{MHz}$, $\mathrm{CDCl}_{3}$ ) was essentially the same as that of cytisine except for the signals at $\delta 5.12(b d, 2 \mathrm{H}, J=12 \mathrm{~Hz})$ and $5.75(\mathrm{~m}, 1 \mathrm{H})$ indicating the presence of vinylic protons. The MS of the new alkaloid displayed a $\mathbf{M}^{+}$at $m / e 230$ together with the base peak at $m / e 189$ suggesting the loss of an allylic group from the parent ion. The remainder of the MS contained fragment peaks characteristic of cytisine.

Catalytic hydrogenation of the new alkaloid over $\mathrm{PtO}_{2}$ gave a product which was identical (TLC, GLC, MS) with the reduction product of angustifoline. The observation that both alkaloids were reduced under the same conditions to give tetrahydrodeoxyangustifoline confirmed the identity of the new base as 11-allylcytisine 1 .

At the present time many of the postulated intermediates in quinolizidine alkaloid biosynthesis have been isolated from $S$. secundiflora. Based on biosynthetic precedents, 11-allylcytisine appears to be biosynthetically positioned between the tetracyclic anagyrine and the tricyclic cytisine. Likewise, rhombifoline may be an intermediate between anagyrine and $N$-methylcytisine and/or cytisine.

\section{EXPERIMENTAL}

Mps are uncorr. IR spectra were recorded neat. ${ }^{1} \mathrm{H}$ NMR spectra were determined on a $100 \mathrm{MHz}$ instrument with TMS as int. standard. MS were measured at $70 \mathrm{eV}$ on an instrument combined with GLC and interfaced with a data system.

Frozen green, unripe fruits $(440 \mathrm{~g})$ of $S$. secundiflora collected on the Amistad Recreation Area near Del Rio, Texas on 3 April, 1977, were homogenized with EtOH and processed as described in [6] to give a crude alkaloid extract. PLC of the crude extract on $\mathrm{Si}$ gel $(1 \mathrm{~mm})$ with $\mathrm{CHCl}_{3}-\mathrm{MeOH}-18 \mathrm{M}$ $\mathrm{NH}_{4} \mathrm{OH} \quad(100: 10: 1)$ gave bands containing $\beta$-isosparteine, lupanine, and rhombifoline. These known alkaloids were identified as being present in the band extracts by spectral and chromatographic comparisons with reference standards. Rechromatography of one band extract on $\mathrm{Si}$ gel layers $(1 \mathrm{~mm})$ with cyclohexane- $\mathrm{CHCl}_{3}-\mathrm{MeOH}$-diethylamine (10:1:1:1) resulted in the isolation of 1 as a thick brown oil. IR $v_{\max }^{\text {Neat }} \mathrm{cm}^{-1}$ 2700-2800 (trans-quinolizidine), $1645(\alpha$-pyridone $\mathrm{C}=\mathrm{O})$ and $914\left(-\mathrm{CH}=\mathrm{CH}_{2}\right) .{ }^{1} \mathrm{H}$ NMR $\left(\mathrm{CDCl}_{3}\right): \delta 1.26-3.32(8 \mathrm{H}, m)$, $4.01\left(2 \mathrm{H}, m, \mathrm{C}-10 \mathrm{CH}_{2}\right), 5.12\left(2 \mathrm{H}, b d, J=12 \mathrm{~Hz}, \mathrm{C}-16 \mathrm{CH}_{2}=\mathrm{C}\right)$, $5.75(1 \mathrm{H}, m, \mathrm{C}-15 \mathrm{CH}=\mathrm{C}), 6.01(1 \mathrm{H}, d d, J=7,1.5 \mathrm{~Hz}, \mathrm{C}-5 \mathrm{H})$ $6.42(1 \mathrm{H}, d d, J=9,1.5 \mathrm{~Hz}, \mathrm{C}-3 \mathrm{H}), 7.3(1 \mathrm{H}, d d, J=9,7 \mathrm{~Hz}$ $\mathrm{C}-4 \mathrm{H})$. MS $(70 \mathrm{eV}): m / e 230\left(\mathrm{M}^{+}\right), 189(100), 160,147,146,117$, 93,84 . After recording these spectral data, the base was treated with $70 \% \mathrm{HClO}_{4}$ to give $30 \mathrm{mg}$ of white needles $\left(\mathrm{EtOH}-\mathrm{Ft}_{2} \mathrm{O}\right.$ ), mp $183-184^{\circ} ;[\alpha]_{D}^{26}-215^{\circ}(\mathrm{MeOH}, c 0.006)$. The perchlorate salt of the new alkaloid $(5 \mathrm{mg})$ dissolved in $5 \mathrm{ml} 15 \% \mathrm{HCl}$ was hydrogenated over $\mathrm{PtO}_{2}$ at room temp. The reduction product was chromatographically (TLC, GLC) and spectrally (MS) identical with tetrahydrodeoxyangustifoline. Reference tetrahydrodeoxyangustifoline was obtained by reducing authentic angustifoline as described above.

Acknowledgements-This research was supported by NIDA grant 1-R01-DA-01731-01. The authors thank Dr. S. I. Goldberg 
(University of New Orleans) for the sample of $\beta$-isosparteine, Dr. O. E. Edwards (Canadian National Research Council) for reference rhombifoline, and Dr. M. Wiewiorowski (Polish Academy of Sciences) for authentic angustifoline.

\section{REFERENCES}

1. Schultes, R. E. (1969) Sciences 163, 245.
2. Schultes, R. E (1970) Annu. Rev. Plant Physiol. 21, 571.

3. Farnsworth, N. R. (1972) J. Psychedelic Drugs 5, 67.

4. Superweed, M. J. (1970) Herbal Highs, p. 6. Stone Kingdom Syndicate, San Francisco.

5. Keller, W. J. (1975) Phytochemistry 14, 2305.

6. Hatfield, G. M. Valdes, L. J. J., Keller, W. J. Merrill, W. L. and Jones, V. H. (1977) Lloydia 40, 374.

\title{
ERYSOPINOPHORINE, A NEW QUATERNARY ALKALOID FROM PODS OF ERYTHRINA ARBORESCENS
}

\author{
K. P. TIWARI and M. Masood \\ Department of Chemistry, University of Allahabad, Allahabad, India
}

(Revised received 19 April 1979)

Key Word Index-Erythrina arborescens; Leguminosae; new quaternary alkaloid; erysopinophorine.

\section{INTRODUCTION}

Erythrina arborescens is distributed throughout the upper Gangetic plains, Assam and Manipur, extending west towards Nepal [1]. The seed of this plant has been reported to contain erysodine, erysovine, erysopine, hypaphorine, erythrascine, orientaline and erysophorine $[2,3]$, and the pod walls have been showed to contain erysodine, orientaline, hypaphorine and erysodinophorine [4]. In this paper we report the isolation of a new quaternary alkaloid 1 , provisionally named erysopinophorine, from the pod walls.

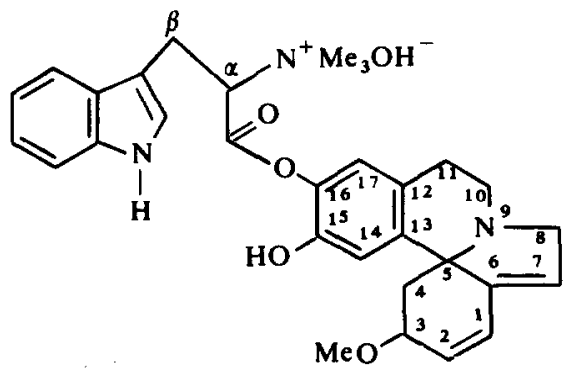

1

\section{RESULTS AND DISCUSSION}

The EtOH extract of pod walls of $E$. arborescens yielded a new alkaloid 1 besides other already reported alkaloids [4]. Hydrolysis of this alkaloid with EtOH$\mathrm{HCl}$ afforded hypaphorine and erysopine. The molecular formula, $\mathrm{C}_{31} \mathrm{H}_{37} \mathrm{~N}_{3} \mathrm{O}_{5}$, of 1 was established from elemental analysis, the integrals of the proton signals $(33 \mathrm{H}$ in $\mathrm{D}_{2} \mathrm{O}$ ) and from the molecular formulae of the products of hydrolysis of erysopinophorine. Like erysophorine and erysodinophorine, 1 also did not respond to the Ehrlich test for $\alpha$-and $\beta$-unsubstituted indoles, whereas the acidhydrolysed product gave a positive test. The negative response by 1 was probably caused by the bulky ester function which blocks the free position of the indole ring $[3,4]$. The UV spectrum of 1 is very similar to that of erysophorine and erysodinophorine, indicating its marked structural similarity $[3,4]$. The compound showed major bands in the IR at 3400 (broad OH and NH), 1762 (phenolic ester group), 1618 (indole ring), $1590,1498,1262$ and 1086 (spiro amine ring) $\mathrm{cm}^{-1}$. The absence of a peak at $1442 \mathrm{~cm}^{-1}$ in the IR of 1 suggests the absence of a $\mathrm{COO}^{-}$group, further supporting the fact that the two alkaloidal fragments are linked together by an ester group.

Since there are two $\mathrm{OH}$ groups at $\mathrm{C}-15$ and $\mathrm{C}-16$ in erysopine, in order to establish the position of esterification, 1 was methylated and hydrolysed with EtOH$\mathrm{HCl}$ whereupon two alkaloids, hypaphorine and erysodine, were obtained indicating that hypaphorine is linked to C-16 of erysopine. 1 did not exhibit an $\mathrm{M}^{+}$peak in its MS but significant fragment ions appeared corresponding to the aromatic erythra-1,6-diene and hypaphorine $[3,4]$. The ${ }^{1} \mathrm{H}$ NMR spectrum of the alkaloid in $\mathrm{D}_{2} \mathrm{O}$ showed signals at $\delta 1.98(1 \mathrm{H}, \mathrm{C}-4 \mathrm{a} \mathrm{H}), 2.45$ (1 H, C-4e H), $3.16\left(9 \mathrm{H}, \mathrm{N}^{+}(\mathrm{Me})_{3}\right), 3.42(3 \mathrm{H}, \mathrm{C}-3 \mathrm{OMe})$, $3.56\left(4 \mathrm{H}, \beta \mathrm{CH}_{2}\right.$ and $\left.\mathrm{C}-8 \mathrm{CH}_{2}\right), 3.94(4 \mathrm{H}, \mathrm{C}-10, \mathrm{C}-11$ $\left.\mathrm{CH}_{2}\right), 4.02(1 \mathrm{H}, \mathrm{C}-3 \mathrm{H}), 4.42(1 \mathrm{H}, \mathrm{C}-\alpha \mathrm{H}), 5.86(1 \mathrm{H}, \mathrm{C}-7 \mathrm{H})$, $6.06(1 \mathrm{H}, \mathrm{C}-1 \mathrm{H}), 6.66(1 \mathrm{H}, \mathrm{C}-2 \mathrm{H})$ and $6.6-7.7(7 \mathrm{H}, \mathrm{C}-14$ $\mathrm{H}, \mathrm{C}-17 \mathrm{H}$ and 5 protons of the indole ring).

The foregoing evidence is in conformity with the structure 1 for erysopinophorine.

\section{EXPERIMENTAL}

The powdered, air-dried and defatted pod walls $(3 \mathrm{~kg})$ of E. arborescens (supplied by United Chemical and Allied Pro- 